\title{
Assessment of genetic diversity in Moroccan sesame (Sesamum indicum) using ISSR molecular markers
}

\author{
Meriem El Harfi ${ }^{1,2}$, Jamal Charafi ${ }^{1}$, Karim Houmanat ${ }^{1}$, Hafida Hanine ${ }^{2}$ and Abdelghani Nabloussi ${ }^{1,{ }^{*}}$ \\ ${ }^{1}$ National Institute of Agronomic Research, Regional Agronomic Research Center, Meknès, Morocco \\ 2 Department of Biology, Faculty of Science and Technics, Sultan Moulay Slimane University, Béni Mellal, Morocco
}

Received 17 June 2020 - Accepted 7 December 2020

\begin{abstract}
There is a need for sesame (Sesamum indicum L.) breeding in Morocco to release performant and adapted varieties, which requires a large genetic variability in the germplasm to be used. In this context, genetic diversity of sesame populations from different locations in Tadla area was investigated using ISSR (Inter Sequence Simple Repeats) markers as a simple method to reveal polymorphism among them. A total of 130 individuals representing 31 populations were sampled. Twenty-four ISSR primers were used for analysis of individuals representing the 31 different sesame populations grown in different agroclimatic zones of Tadla, accounting for $90 \%$ of sesame cultivation area in Morocco. Indeed, seven primers showed legible and reproducible genomic profiles with an interesting number of bands. A total of 57 bands were obtained with ISSR primers, of which 47 were polymorphic. PIC (Polymorphic Information Content) ranged from 0.002 to 0.350 , showing that ISSR markers are informative and relevant for discriminating the populations evaluated. The similarity coefficient of ISSR data ranged from 0.509 to 1 , with an average of 0.870 . The results obtained showed that Moroccan sesame populations are characterized by a low genetic diversity, suggesting a genetic proximity among them. Therefore, new germplasm should be either introduced from diverse geographical origins or created through mutagenesis breeding in order to broaden the existing genetic variability.
\end{abstract}

Keywords: genetic diversity / ISSRs markers / Morocco / polymorphism / Sesamum indicum L.

Résumé - Évaluation de la diversité génétique du sésame marocain (Sesamum indicum) à travers l'utilisation de marqueurs moléculaires ISSR. Au Maroc, il y a un besoin en amélioration génétique du sésame (Sesamum indicum L.) pour développer des variétés performantes et adaptées, ce qui nécessite une grande variabilité génétique dans le germoplasme de cette culture. Dans ce contexte, la diversité génétique des populations de sésame de différentes localités de la zone du Tadla a été étudiée en utilisant les marqueurs ISSR (Inter Sequence Simple Repeats) comme méthode simple pour révéler le polymorphisme entre elles. Un total de 130 individus représentant 31 populations a été échantillonné. Vingt-quatre amorces ISSR ont été utilisées pour l'analyse d'individus représentant les 31 différentes populations de sésame cultivées dans différentes zones agroclimatiques du Tadla qui totalise $90 \%$ de la superficie globale du sésame au Maroc. Sept amorces ont montré des profils génomiques lisibles et reproductibles avec un nombre intéressant de bandes. En effet, 57 bandes ont été obtenues avec les amorces ISSR, dont 47 étaient polymorphes. L'indice de polymorphisme (PIC) varie de 0,002 à 0,350 , montrant que les marqueurs ISSR sont informatifs et pertinents pour discriminer les populations évaluées. Le coefficient de similarité des données ISSR varie de 0,509 à 1 , avec une moyenne de 0,870 . Les résultats obtenus ont montré que les populations marocaines de sésame sont caractérisées par une faible diversité génétique, suggérant une proximité génétique entre elles. Par conséquent, un nouveau matériel génétique devrait être soit introduit de différentes origines géographiques, soit développé par mutagenèse, afin d'élargir la variabilité génétique existante.

Mots clés : diversité génétique / marqueurs ISSR / Maroc / polymorphisme / Sesamum indicum L.

*Correspondence: abdelghani.nabloussi@gmail.com 


\section{Introduction}

Sesame (Sesamum indicum L., $2 n=26$ ) is the most ancient annual oilseed crop grown in both tropical and temperate zones (Bedigian and Harlan, 1986). It is ranked ninth among the top 13 oilseed crops that ensure $90 \%$ of the global edible oil production (Adeola et al., 2010). It is predominantly a selfpollinated diploid plant $(2 n=26)$, with seeds that are rich in oil (50-60\%) and antioxidants (Uzun et al., 2007). It is a source of protein, high-quality edible oil with elevated level of polyunsaturated fatty acids and various minor nutrients, such as vitamins, minerals and important characteristic antioxidant lignans (sesamin, sesamolin, sesamol) (Dar and Arumugam, 2013; Pathak et al., 2017). Sesame seeds and their oil, having long been used for human consumption and different industrial purposes, have recently attracted much attention due to the high oil quality, with high content of oleic and linoleic acids (Dar et al., 2019a). The plant is cultivated in many countries of the Asian, African and American continents and has been growing over 5000 years. However, sesame is still a poorly investigated crop. In 2017, about 10 million hectares were harvested worldwide, producing more than 5.5 million tons of seed, with an average yield of $0.55 \mathrm{t} / \mathrm{ha}$ (FAOSTAT, 2018). A total of $70 \%$ of the world production comes from Asia and $26 \%$ from Africa. Actually, the largest producers of sesame in the world are India, Myanmar, China, Sudan, Uganda, Ethiopia and Nigeria (FAOSTAT, 2018).

Sesame genome size, which is about $350 \mathrm{Mb}$, is not largely explored. A number of 27,148 genes have been annotated in a sesame reference genome that shows a low proportion of repetitive sequences $(28.5 \%)$ (Wang et al., 2014). Besides, the available genetic diversity in sesame germplasm is relatively limited as during sesame evolution many valuable genes associated with high yield might have been lost. Also, limited use of landraces in contemporary sesame breeding programs has probably narrowed the genetic basis of cultivated sesame (Spawan et al., 2019).

In Morocco, despite sesame has been grown during hundred years, yield and production are still too low. National production is around 1000 tons on an area harvested of about 840 ha, for an average seed yield of $1.12 \mathrm{t} / \mathrm{ha}$ (FAOSTAT, 2018). Tadla zone, belonging to Béni Mellal-Khénifra region, is the most important area of sesame production, with almost $90 \%$ of the global cultivated area in the country. Moroccan sesame remains undeveloped because of several constraints, including the uncharacterized plant material cultivated and the non-use of improved varieties. This situation can be changed by developing and releasing productive varieties of good quality and high adaptive potential to environmental conditions of this crop cultivation. Prior to that, genetic information on local landraces is needed and the existing genetic diversity should be explored. In this context, a number of local sesame populations or cultivars were collected and characterized, for the first time, using some morphological and agronomic traits (El Harfi et al., 2018). The genetic variability revealed was too narrow for most of the studied traits, suggesting these cultivars are genetically very close. Additional molecular analysis of those plant materials was recommended to better investigate the existing genetic diversity among them and to confirm or refute the findings of agromorphological study (E1 Harfi et al., 2018). Particularly, DNA markers are useful and reliable as they remain stable under different environmental conditions (Ferdinandez et al., 2001; Dar et al., 2019b). Genetic diversity in sesame over the world has been assessed using different molecular techniques namely, RAPD (Random Amplified Polymorphic DNA) (Salazar et al., 2006; Dar et al., 2017), AFLP (Amplified Fragment Length Polymorphism) (Laurentin and Karlovsky, 2006), ISSR (Inter Simple Sequence Repeats) (Kim et al., 2002; Kumar and Sharma, 2011; Nyongesa et al., 2013; Abate et al., 2015; Woldesenbet et al., 2015), SSR (Simple Sequence Repeat) (Uncu et al., 2015; Sehr et al., 2016; Dossa et al., 2017), and SRAP (Sequence Related Amplified Polymorphism) (Zhang et al., 2010). ISSR are DNA based markers having primers with simple repetitive sequences of two, four or five nucleotides, and known to be simple, fairly stable and highly reproducible (Houmanat et al., 2016). Also, they are a reliable tool that gives good information on the level of diversity (Chen et al., 2014). Therefore, the objective of this work was to analyze the genetic diversity among the sesame local Moroccan populations, from Tadla area, using ISSR markers. This will allow us to confirm or deny the results of the phenotypic characterization reported by El Harfi et al. (2018) and, then, to make appropriate decision with regard to sesame breeding program to be undertaken.

\section{Material and methods}

\subsection{Plant material}

The plant material investigated was composed of 31 sesame local populations that were collected from different locations of Tadla area in Morocco, and then assessed for some morphological and agronomic traits (El Harfi et al., 2018). The Tadla area that lies at an altitude between 450 and $470 \mathrm{~m}$ is characterized by an arid to semi-arid climate with a wet season from November to March and a dry one from April to October. The annual rainfall is around $370 \mathrm{~mm}$, while the average temperature is about $19^{\circ} \mathrm{C}$, with a maximum above $40^{\circ} \mathrm{C}$ and a minimum below $1{ }^{\circ} \mathrm{C}$. The codes of the populations collected along with the geographical coordinates of collecting locations are shown in the Table 1. Five individuals per population were analyzed. However, due to technical problem, 25 individuals did not show a good molecular profile and thus were eliminated. At the end, a total of 130 individuals, representing the 31 populations, were considered for this study.

\subsection{DNA isolation}

Genomic DNA was isolated from young leaves of each plant following the Cetyl Trimethyl Ammonium Bromide (CTAB) modified method of Saghai-Maroof et al. (1984). The quality of the extracted DNA was first verified on agarose gel $(0.8 \%)$. The amount and purity of DNA extracted were evaluated by measuring the OD (Optical Density) at $260 \mathrm{~nm}$ and at $280 \mathrm{~nm}$ to detect contamination. Indeed, the more the ratio OD260/OD280 tends to 2, the more the DNA extract is better or pure, and its use in several amplification techniques is doomed to success. 
Table 1. Identification of the 31 Moroccan sesame populations used in the present study according to the codes of a previous agromorphological study (E1 Harfi et al., 2018).

\begin{tabular}{|c|c|c|}
\hline Populations number & Code & Geographical coordinates \\
\hline 1 & BA & $33.21^{\circ} \mathrm{N}, 6.72^{\circ} \mathrm{W}$ \\
\hline 2 & TG2 & $32.44^{\circ} \mathrm{N}, 6.20^{\circ} \mathrm{W}$ \\
\hline 3 & KR1 & $32.24^{\circ} \mathrm{N}, 6.22^{\circ} \mathrm{W}$ \\
\hline 4 & KR2 & $32.24^{\circ} \mathrm{N}, 6.22^{\circ} \mathrm{W}$ \\
\hline 5 & $\mathrm{OZ2}$ & $32.30^{\circ} \mathrm{N}, 6.26^{\circ} \mathrm{W}$ \\
\hline 6 & OY1 & $32.43^{\circ} \mathrm{N}, 6.33^{\circ} \mathrm{W}$ \\
\hline 8 & TG1 & $32.44^{\circ} \mathrm{N}, 6.20^{\circ} \mathrm{W}$ \\
\hline 9 & OY2 & $32.43^{\circ} \mathrm{N}, 6.33^{\circ} \mathrm{W}$ \\
\hline 10 & HB1 & $32.24^{\circ} \mathrm{N}, 6.95^{\circ} \mathrm{W}$ \\
\hline 11 & HB2 & $32.24^{\circ} \mathrm{N}, 6.95^{\circ} \mathrm{W}$ \\
\hline 12 & OB1 & $32.13^{\circ} \mathrm{N}, 6.53^{\circ} \mathrm{W}$ \\
\hline 13 & TG3 & $32.44^{\circ} \mathrm{N}, 6.20^{\circ} \mathrm{W}$ \\
\hline 14 & TG4 & $32.44^{\circ} \mathrm{N}, 6.20^{\circ} \mathrm{W}$ \\
\hline 15 & $\mathrm{SE}$ & $32.45^{\circ} \mathrm{N}, 6.53^{\circ} \mathrm{W}$ \\
\hline 16 & TG8 & $32.44^{\circ} \mathrm{N}, 6.20^{\circ} \mathrm{W}$ \\
\hline 17 & LZ1 & $32.26^{\circ} \mathrm{N}, 6.23^{\circ} \mathrm{W}$ \\
\hline 18 & OB2 & $32.13^{\circ} \mathrm{N}, 6.53^{\circ} \mathrm{W}$ \\
\hline 19 & $\mathrm{KF}$ & $32.31^{\circ} \mathrm{N}, 6.36^{\circ} \mathrm{W}$ \\
\hline 20 & $\mathrm{LZ2}$ & $32.26^{\circ} \mathrm{N}, 6.23^{\circ} \mathrm{W}$ \\
\hline 21 & OZ1 & $32.30^{\circ} \mathrm{N}, 6.26^{\circ} \mathrm{W}$ \\
\hline 22 & TG6 & $32.44^{\circ} \mathrm{N}, 6.20^{\circ} \mathrm{W}$ \\
\hline 25 & TG7 & $32.44^{\circ} \mathrm{N}, 6.20^{\circ} \mathrm{W}$ \\
\hline 27 & $\mathrm{SS} 1$ & $32.30^{\circ} \mathrm{N}, 6.70^{\circ} \mathrm{W}$ \\
\hline 28 & LZ3 & $32.26^{\circ} \mathrm{N}, 6.23^{\circ} \mathrm{W}$ \\
\hline 29 & HB3 & $32.24^{\circ} \mathrm{N}, 6.95^{\circ} \mathrm{W}$ \\
\hline 30 & $\mathrm{OM}$ & $32.28^{\circ} \mathrm{N}, 6.46^{\circ} \mathrm{W}$ \\
\hline 31 & LZ4 & $32.26^{\circ} \mathrm{N}, 6.23^{\circ} \mathrm{W}$ \\
\hline 32 & HB4 & $32.24^{\circ} \mathrm{N}, 6.95^{\circ} \mathrm{W}$ \\
\hline 33 & KR3 & $32.24^{\circ} \mathrm{N}, 6.22^{\circ} \mathrm{W}$ \\
\hline 34 & KR4 & $32.24^{\circ} \mathrm{N}, 6.22^{\circ} \mathrm{W}$ \\
\hline 35 & $\mathrm{SS} 2$ & $32.30^{\circ} \mathrm{N}, 6.70^{\circ} \mathrm{W}$ \\
\hline
\end{tabular}

\subsection{Amplification of the sesame DNA by ISSR markers}

ISSR analysis based on PCR was carried out using 24 ISSR primers selected from several studies (Medraoui et al., 2007; Houmanat et al., 2016). Gradient PCR was used to adjust the annealing temperature of each primer. Primer sequences and melting temperatures are shown in Table 2. DNA was amplified by PCR in a total volume of $25 \mu \mathrm{L}$. The composition of the reaction mixture is $15 \mathrm{ng} / \mu \mathrm{L}$ of DNA, $5 \mu \mathrm{L}$ of PCR tampon $(\times 10), \quad 50 \mathrm{mM}$ of $\mathrm{MgCl}_{2}, 2.5 \mathrm{mM}$ of dNTP, $10 \mathrm{pmol} / \mu \mathrm{L}$ of each ISSR primer and 2 units DNA polymerase (Invitrogen). The ideal hybridization temperatures of each primer were chosen from the results of the PCR gradient test (temperatures of 44 to $60.5^{\circ} \mathrm{C}$ ). The amplification was executed in the Eppendorf Master Cycler gradient. The PCR reactions were conducted faithfully according to the program of the following thermal cycle: initial denaturation at $94^{\circ} \mathrm{C}$ for 4 min followed by 40 cycles with a denaturation of the DNA at $94{ }^{\circ} \mathrm{C}$ for $1 \mathrm{~min}$, hybridization of the primer at the corresponding hybridization temperature for $1 \mathrm{~min}$, extension of the primer at $72{ }^{\circ} \mathrm{C}$ for $1 \mathrm{~min}$. Amplification is sealed off by final elongation step at $72{ }^{\circ} \mathrm{C}$ for $6 \mathrm{~min}$. The ISSR amplification products were separated by electrophoresis on $2 \%$ agarose gel in TBE buffer for 2.5 hours at 150 volts. After staining with ethidium bromide $(0.1 \%)$, the gel is visualized under UV and photographed and stored on computer for subsequent treatment by Mesurim software. A $1 \mathrm{~kb}$ DNA ladder (Invitrogen) was used for molecular weight estimation of PCR products.

\subsection{Scoring and data analysis}

A data matrix was created by scoring ISSR bands from gels as 1 and 0 for their presence and absence, respectively. Only clear, unambiguous bands between 300 and $1800 \mathrm{bp}$ were recorded.

The genetic distances and similarities were calculated using simple matching coefficient (SMC) by Clustering Calculator software program established by Brzustowski (2002). Thus, based on the pairwise comparisons of genotypes, a histogram according to the number of markers which distinguish them has been established. Characterization of primers for their ability to differentiate the studied genotypes was assessed by calculating polymorphic information content (PIC). PIC was calculated according to the formula of Anderson et al. (1993), as:

$$
P I C_{i}=n\left(1-\sum_{j} P i j^{2}\right) \div(n-1),
$$

where $j$ is the primer concerned, $n$ is the size of $i$ bands and $P i j$ is the frequency of marker $I$ revealed by the primer $j$ through the band sum.

Cluster analysis was performed to construct dendrograms, with the unweighted pair-group method by arithmetic averages (UPGMA) from the similarity data matrices using simple matching coefficient. The numerical taxonomy and multivariate analysis system program package for personal computer (NTSYSPC V.2.02.; Rohlf, 1998) was used for statistical analysis of data.

\section{Results and discussion}

\subsection{ISSR genotyping}

Among the 24 ISSR primers tested, seven primers (29\%) have been chosen according to their clear and reproducible profiles (Tab. 3). The other 17 primers (71\%) have generated ambiguous and non-readable amplification profiles. Figure 1 shows an example of a molecular profile revealed by the F9 primer. The seven ISSR primers amplified 57 bands of which 46 were polymorphic $(80.7 \%)$, suggesting that these primers are effective for exploring molecular polymorphism in Moroccan sesame and reflecting the existence of genetic variability. The highest number of total amplified bands was 14 with the primer F11, while the lowest number of total amplified bands was 1 with the primer IMA8Z, with an average of 6.57 bands per primer (Tab. 3). The observed band sizes of all amplification fragments ranged from 329 to $1795 \mathrm{bp}$ (Tab. 3).

The highest polymorphism rate was observed with F7, F9, F11 and UBC 807 primers, all showing $100 \%$ of the 
Table 2. List of 24 ISSR primers used in the genetic characterization of 31 sesame populations.

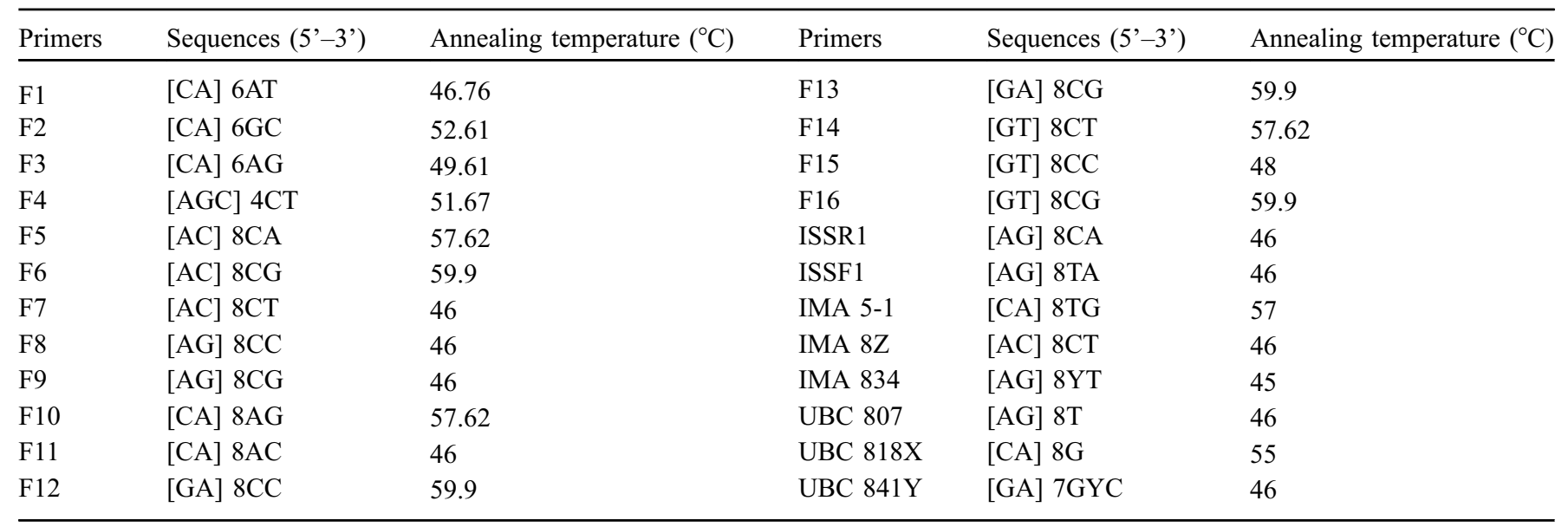

Table 3. Marker attribute information of 7 different ISSR primers tested with 31 populations of Moroccan sesame.

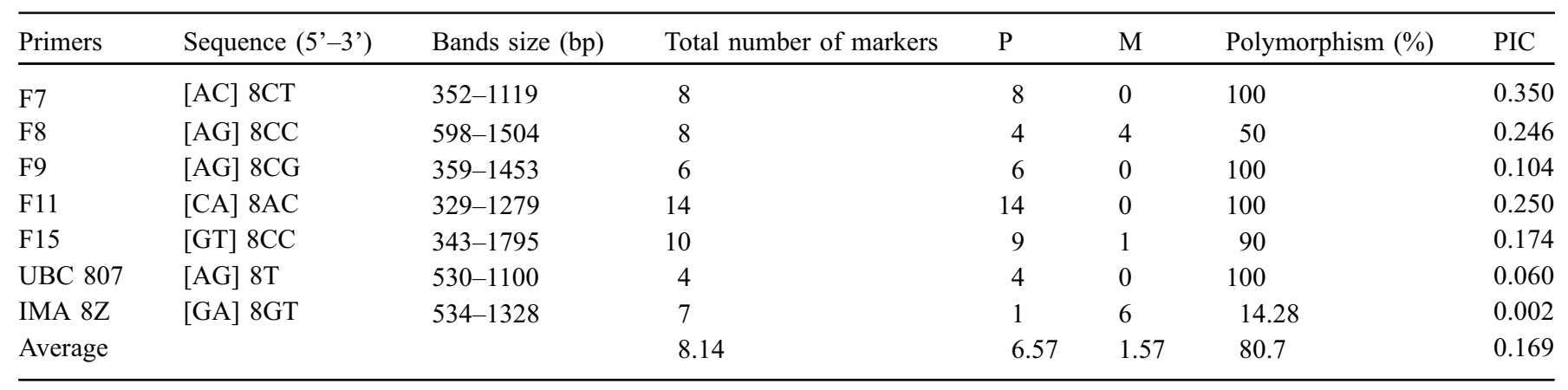

P: polymorphic markers; M: monomorphic markers; PIC: Polymorphic Information Content.

polymorphic bands, while the minimum polymorphism rate was found with the IMA8Z primer $(14.28 \%)$. The average polymorphism rate was about $80.7 \%$.

\subsection{Genetic similarity}

According to the simple matching coefficient, similarity index values ranged from 0.509 to 1.000 , with an average of 0.870 . The highest similarity (1) was recorded between 537 pairs of individuals or genotypes, from the 31 populations studied, indicating that they have the same genetic profile. The lowest similarity coefficient was found between an individual of the population LZ2 (LZ2-5) and an individual of the population KF (KF-2), and between KF-2 and an individual of the population TG6 (TG6-5), suggesting a maximal genetic distance between the three individuals or genotypes. Twentyeight different markers differentiate these individuals (Fig. 2). Among the total 8385 pairwise combinations, a number of $6244(74.46 \%)$ were differentiated by less than 11 markers, while the other 2141 pairs were distinguished by 11 to 28 markers (Fig. 2). This explains the low diversity among the studied populations of Moroccan sesame.

\subsection{Polymorphism Information Content}

All primers used generated polymorphic profiles with variable and significant polymorphic information content

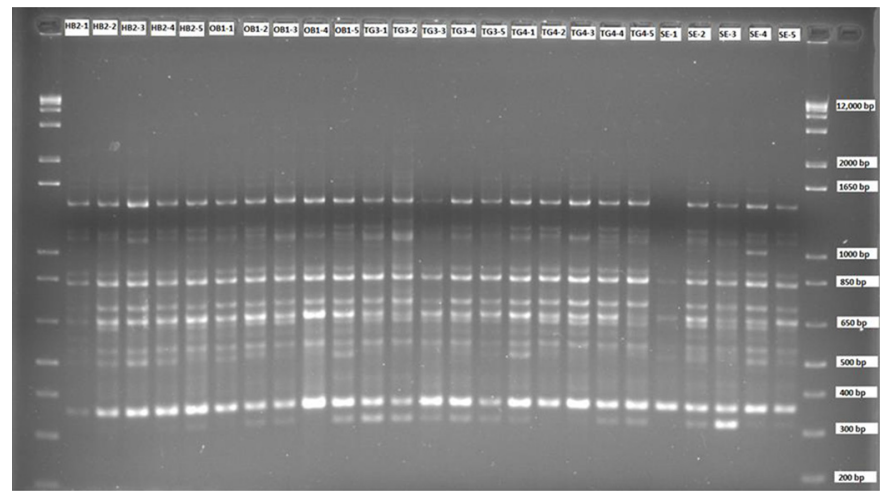

Fig. 1. PCR amplification profile of the ISSR F9 primer for 25 samples from the sesame populations analyzed.

(Tab. 3). Indeed, the study confirmed the genetic variability of the seven primers used. The difference in the Polymorphic Information Content (PIC) reveals the difference in the degree of ability to differentiate the genotypes. For a given primer, the more its value tends to 1 , the more it is polymorphic and vice versa. The lowest PIC is 0.002 observed in primer IMA8Z, indicating the lowest diversity of this primer. The highest PIC $(0.35)$ is found in F7 primer which gives $100 \%$ polymorphic bands, confirming its greatest ability to distinguish between genotypes. The average PIC registered is 0.169 , which remains 


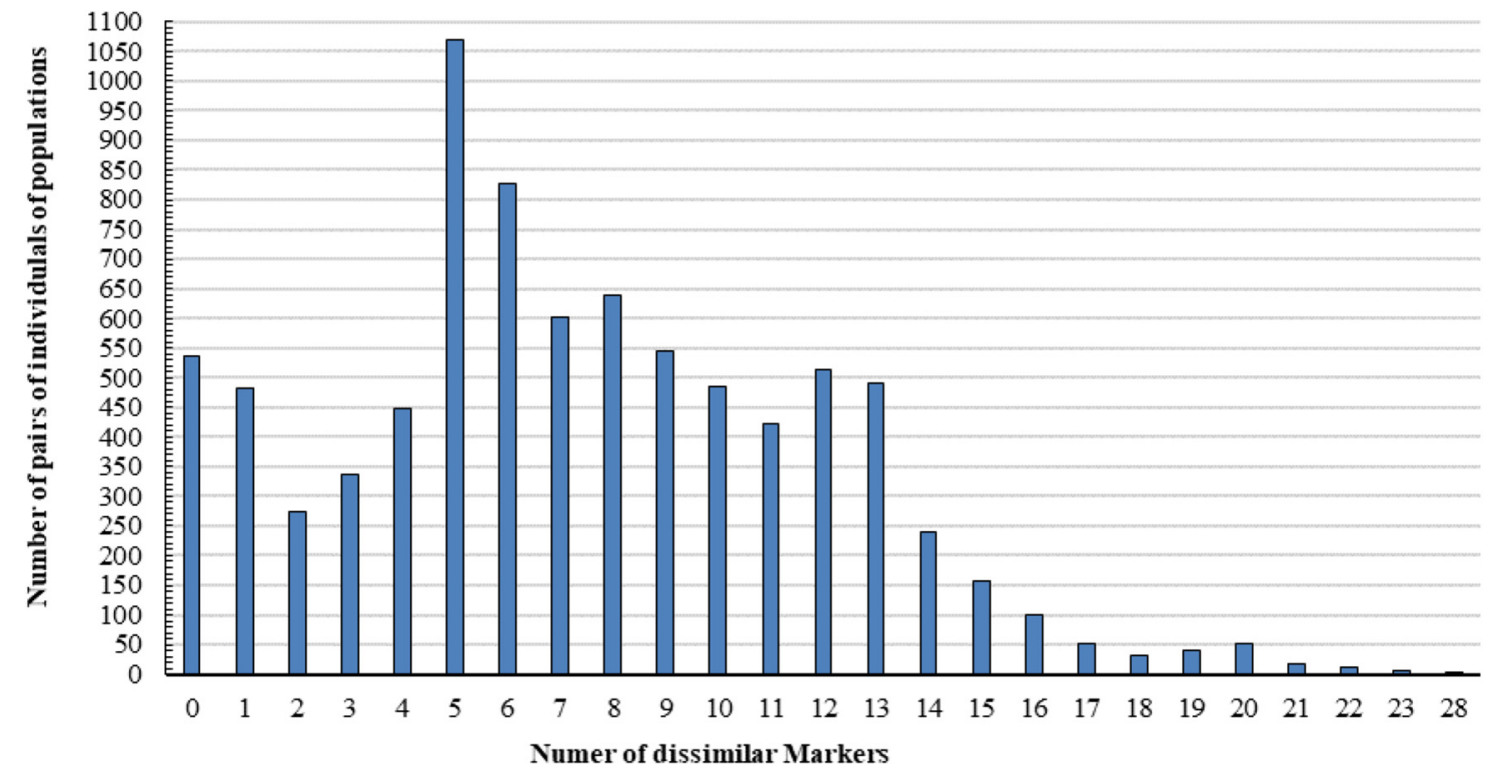

Fig. 2. Frequencies distribution of genetic dissimilarity for all the Moroccan sesame populations' pairs.

too low and indicates a weak polymorphism among the Moroccan sesame populations studied.

\subsection{Genetic relationship among Moroccan sesame populations according to cluster analysis}

The dendrogram obtained (Fig. 3) illustrates the genetic relationships between individuals of the 31 populations investigated. The first observation, a primary differentiation into two main groups (I and II, Fig. 3) was observed at a similarity coefficient of 0.83 . However, the important distinction of genotypes appears at a level above a coefficient of 0.885 . Three clusters and seven independent branches were distinguished. The first cluster A includes more than $58.46 \%$ of individuals of Moroccan sesame populations, containing individuals from populations; $1,2,3,4,5,6,8,9,10,20$, $21,22,25,27,28,29,30$ and 31 . Clusters $B$ and $C$ include, respectively, $12.30 \%$ and $23.84 \%$ of individuals. According to the Figure 3, the individuals of the populations $32,33,34$ and 35 are found in the same cluster B. The group corresponding to cluster $\mathrm{C}$ consisted of individuals from the populations 11,12 , $13,14,15,16,17,18$ and 19. Therefore, the dendrogram confirms the pairwise comparison, showing that several individuals have the same genetic profiles.

The use of a high number of polymorphic ISSR primers is of great utility as it increases the reliability of the interpretation of the results, especially if the generated profiles are reproducible (Handaji et al., 2012). This number varies according to plant species analyzed and differs from one study to another. The number of primers used in the present research was just seven, which was equal to that used for analyzing the genetic diversity in Ethiopian Sesame germplasm (Abate et al., 2015). However, smaller number of ISSR primers was adopted to study the genetic diversity in other annual species, for example five primers in Brassica napus (Abdelmigid, 2012) and Melocanna baccifera (Nilkanta et al., 2017). The average polymorphism rate obtained in this study $(80.7 \%)$ is higher than that reported in previous works using ISSR markers to investigate the genetic diversity in sesame from Africa and wild relatives $(70.6 \%)$ (Nyongesa et al., 2013), Ethiopian sesame (75.86\%) (Woldesenbet et al., 2015), Indian sesame (57\%) (Kumar and Sharma, 2011) and Korean sesame (33\%) (Kim et al., 2002). In contrast, the average polymorphism rate is lower than that reported by Anitha et al. (2010) (98.5\%), having used ISSR markers, and Salazar et al. (2006) (100\%), having used RAPD markers in the analysis of genetic diversity of Tamil Nadu sesame and Venezuelan sesame varieties, respectively. More recently, in their mapping study in sesame, based on the codominant SSRs markers, Dossa et al. (2017) found $78 \%$ of polymorphism in the population investigated. Differences in polymorphism might be due to the genetic material analyzed, the nature of the ISSR primers and the hybridization temperatures used (Sanchez de la Hoz et al., 1996). Low hybridization temperature can increase nonspecific amplification, leading to artifact bands. It was reported that modification of hybridization temperature greatly affected richness and readability of fingerprints (Bornet and Branchard, 2001).

Polymorphism Information Content (PIC) value is the discriminatory power of primers and used as a relative measure level of polymorphism. In other words, PIC is used to determine the informativeness of a genetic marker for linkage studies. In plants, PIC values often range from zero to 0.5 , respectively for monomorphic ISSR-markers and polymorphic ISSR-markers that are present in $50 \%$ of the plants and absent in the other 50\% (Roldán-Ruiz et al., 2000). In the present study, PIC varied from 0.002 to 0.35 , indicating that ISSR markers are informative and relevant for discriminating the populations evaluated. However, these values remain lower than those obtained by Anitha et al. (2010) in 10 Indian sesame populations (from 0.496 to 0.854), Abate et al. (2015) in Ethiopian sesame (from 0.26 to 0.76 ) and Singh et al. (2015) in 44 Indian sesame populations $(\mathrm{PIC}=0.675$ ). The differences observed among the various studies might be due to the populations used, and the nature and number of molecular markers. 
M. El Harfi et al:: OCL 2021, 28, 3

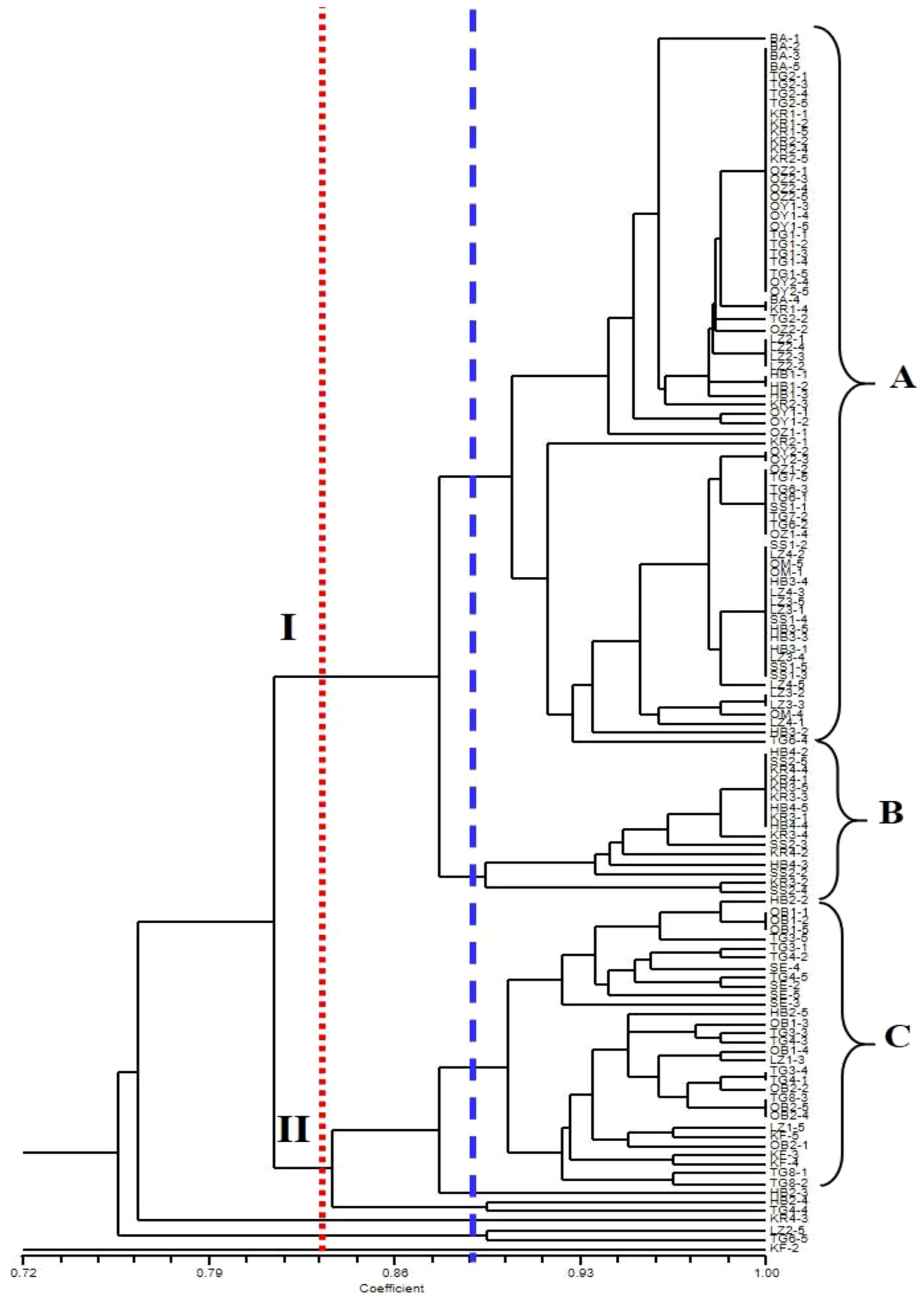

Fig. 3. Dendrogram generated for individuals from 31 Moroccan sesame populations using UPGMA cluster analysis. 
Similarity coefficient between the investigated populations varied from 0.509 to 1 , with an average of 0.87 . The similarity coefficients found between the Moroccan sesame populations are comparable with those reported by Singh et al. (2015) in a collection of 44 Indian sesame genotypes (from 0.65 to 0.87 , with a mean value of 0.76 ). However, wider range of similarity coefficient (from 0.26 to 0.96 ) was observed among populations of cultivated sesame and wild sesame from West Africa (Nyongesa et al., 2013). The quite high average similarity coefficient ( 0.87 ) observed in the present research suggests that the genetic variability among the studied sesame populations is low. High values of this coefficient explain the kinship link existing between these populations collected from Tadla zone that represents the largest area of sesame cultivation in Morocco, with about $90 \%$. This low diversity in Moroccan populations is confirmed by the pairwise comparison in which most combinations are distinguishable by less than 11 markers. Thus, one could notice that several combinations have the same genetic profile. Also, the observed low diversity is confirmed by hierarchical analysis. In fact, the emerged dendrogram shows that the genetic profile of the 31 Moroccan sesame population is close and might be derived from one or few genetic pools only. In contrast, in a similar study in safflower, Houmanat et al. (2016) showed that the majority of pairwise combinations are distinguishable by more than eight markers.

The analysis of the clusters of the dendrogram generated by the ISSR markers shows the existence of correlation between geographical locations and genomic similarity for some populations. This is the case of populations 1 (BA), 30 $(\mathrm{OM}), 6$ (OY1) and 9 (OY2), all grouped in cluster A, and populations 12 (OB1), 18 (OB2), 15 (SE) and $19(\mathrm{KF})$, all found in cluster $\mathrm{B}$. For the other populations, the distribution of sesame populations operates independently from their origin location, indicating no correlation between their geographical origin and their genetic distance. Besides, and in comparison with agromorphological assessment of the studied plant materials, three populations of cluster $\mathrm{C}$ are characterized by high number of seeds per capsule, low height at first capsule and intermediate thousand seeds weight value. These are 32 (HB4), 33 (KR3) and 34 (KR4). Furthermore, individuals of the same population were clustered into the same branch, suggesting there is no intra-population variation.

The findings of this study suggest that the investigated populations might originate from the same cultivar whose name would be 'Blonde of Marrakech' as reported by Skiredj et al. (2003). However, to analyze in depth these populations, additional studies using codominant markers are needed, especially in terms of comparison with foreign genetic resources that can give more information on the diversity level of Moroccan populations and their genetic proximity to those foreign resources. Furthermore, other minor local cultivars from other zones than Tadla should be involved in those upcoming studies.

To launch a sesame breeding program, a large genetic variability should be available. In light of the results obtained, it will be necessary to get additional genetic material to widen the existing variability. The most common strategy is to introduce new germplasms from some sesame producing countries throughout the world. Another strategy may be adopted and consists of inducing novel genetic variability from the existing material using mutagenesis technique.

\section{Conclusion}

This study has given some useful information about the genetic diversity of Moroccan sesame populations. Polymorphism and PIC found in this study indicated that the ISSR markers used were highly reproducible. Although a limited number of ISSR markers were used in the study, the results confirm that ISSR markers are effective in detecting polymorphism between Moroccan sesame populations. However, the high similarity coefficients found between them as well as the pairwise comparison of these populations show that there is a low genetic diversity among them. Thus, this result agrees with that of agromorphological characterization. At $88.5 \%$ similarity, the individuals of the 31 populations of Moroccan sesame were grouped into three large clusters and seven independent branches. Therefore, to find clear patterns of diversity and to have a sound conclusion, further studies should be conducted through comparison with foreign genetic pools, using preferably codominant molecular markers. Besides, in order to launch sesame breeding program in Morocco, new germplasms should be introduced from diverse geographical origins. Otherwise, novel genetic variability may be induced through mutagenesis breeding.

\section{References}

Abate M, Mekbib F, Ayana A, Nigussie M. 2015. Assessment of genetic diversity in Ethiopian sesame (Sesamum indicum L.) germplasm using ISSR markers. Br Biotechnol J 8: 1-13.

Abdelmigid HM. 2012. Efficiency of random amplified polymorphic DNA (RAPD) and inter-simple sequence repeats (ISSR) markers for genotype fingerprinting and genetic diversity studies in canola (Brassica napus). Afr J Biotechnol 11: 6409-6419.

Adeola YB, Augusta CO, Oladejo TA. 2010. Proximate and mineral composition of whole and dehulled Nigerian sesame seeds. Afr $J$ Food Sci Technol 1:71-75

Anderson JA, Churchill GA, Sutrique JE, Tanksley SD, Sorrells ME. 1993. Optimizing parental selection for genetic linkage maps. Genome 36: 181-186.

Anitha BK, Manivannan N, Vindhiyavarman P, Gopalakrishnan C, Ganesamurthy K. 2010. Molecular diversity among sesame varieties of Tamil Nadu. Electron J Plant Breed 1: 447-452.

Bedigian D, Harlan JR. 1986. Evidence for cultivation of sesame in the ancient world. Econ Bot 40: 137-154.

Bornet B, Branchard M. 2001. Nonanchored Inter Simple Sequence Repeat (ISSR) markers: reproducible and specific tools for genome fingerprinting. Plant Mol Biol Rep 19: 209-215.

Brzustowski J. 2002. Clustering calculator "fast clustering algorithms, including UPGMA and Saitou-Nei neighbor joining". Canada: Department of Biological Sciences, University of Alberta. Available from http://www.biology.ualberta.ca/ jbrzusto/cluster.php (last consult: 2020/23/03).

Chen F, Ahmed T, Liu YJ, He KL, Wang ZY. 2014. Analysis of genetic diversity among different geographic populations of Athetis lepigone using ISSR molecular markers. J Asian Pac Entomol 17: 793-798.

Dar AA, Arumugam N. 2013. Lignans of sesame: purification methods, biological activities and biosynthesis - A review. Bioorg Chem 50: 1-10.

Dar AA, Kancharla PK, Chandra K, Sodhi YS, Arumugam N. 2019a. Assessment of variability in lignin and fatty acid content in the germplasm of Sesamum indicum. J Food Sci Technol 56: 976-986. 
Dar AA, Mahajan R, Sharma S. 2019b. Molecular markers for the characterization and conservation of plant genetic resources. Indian J Agric Sci 89: 1755-1763.

Dar AA, Mudigunda S, Mittal PK, Arumugam N. 2017. Comparative assessment of genetic diversity in Sesamum indicum L. using RAPD and SSR markers. 3 Biotech 7: 10.

Dossa K, Yu J, Liao B, Cisse N, Zhang X. 2017. Development of highly informative genome-wide single sequence repeat markers for breeding applications in sesame and construction of a web resource: SisatBase. Front Plant Sci 8: 1470.

El Harfi M, Jbilou M, Hanine H, Rizki H, Fechtali M, Nabloussi A. 2018. Genetic diversity assessment of Moroccan sesame (Sesamum Indicum L) populations using agromorphological traits. J Agric Sci Technol A 8: 296-305.

FAOSTAT. 2018. FAO statistical database. Available from http:// www.fao.org/faostat/en/\#data/QC (last consult: 2019/01/27).

Ferdinandez YSN, Somers DJ, Coulman BE. 2001. Estimation the genetic relationship of hybrid bromegrass to smooth bromegrass and meadow bromegrass using RAPD markers. Plant Breed 120: 149-153.

Handaji N, Benyahia H, Gaboun F, Ibriz M. 2012. Caractérisation et structuration de la diversité génétique du germoplasme de mandarines par les marqueurs moléculaires ISSR au Maroc. J Appl Biosci 57: 4186-4197.

Houmanat K, Charafi J, Mazouz H, El Fechtali M, Nabloussi A. 2016. Genetic diversity analysis of safflower (Carthamus tinctorius L.) accessions from different geographic origins using ISSR markers. Int J Agric Biol 18: 1081-1087.

Kim DH, Zur G, Danin-Poleg Y, et al. 2002. Genetic relationships of sesame germplasm collection as revealed by inter-simple sequence repeats. Plant Breed 121: 259-262.

Kumar V, Sharma SN. 2011. Comparative potential of phenotypic, ISSR and SSR markers for characterization of sesame (Sesamum indicum L.) varieties from India. J Crop Sci Biotechnol 14: 163-171.

Laurentin H, Karlovsky P. 2006. Genetic relationship and diversity in sesame (Sesamum indicum L.) germplasm collection using amplified fragments length polymorphisms (AFLP). BMC Genet 7: $1-10$.

Medraoui L, Ater M, Benlhabib O, Msikine D, Filali-Maltouf A. 2007. Evaluation of genetic variability of sorghum (Sorghum bicolor L. Moench) in northwestern Morocco by ISSR and RAPD markers. C R Biol 330: 789-797.

Nilkanta H, Amom T, Tikendra L, Hamidur R, Nongdam P. 2017. ISSR marker based population genetic study of Melocanna baccifera (Roxb.) Kurz: a commercially important bamboo of Manipur, North-East India. Scientifica 2017: 1-9.

Nyongesa BO, Were BA, Gudu S, Dangasuk OG, Onkware AO. 2013. Genetic diversity in cultivated sesame (Sesamum indicum L.) and related wild species in East Africa. J Crop Sci Biotechnol 16: 9-15.

Pathak K, Rahman SW, Bhagawati S, Gogoi B. 2017. Sesame (Sesamum indicum L.), an underexploited oil seed crop: Current status, features and importance - A review. Agric Rev 38: 223-227.

Rohlf FJ. 1998. NTSYS-pc 2.02. Numerical taxonomy and multivariate analysis system. Setauket, New York, USA: Exeter Software: Applied Biostatistics Inc.

Roldán-Ruiz I, Dendauw J, Van Bockstaele E, Depicker A, De Loose M. 2000. AFLP markers reveal high polymorphic rates in ryegrasses (Lolium spp.). Mol Breed 6: 125-134.

Saghai-Maroof MA, Soliman KM, Jorgensen RA, Allard RW. 1984. Ribosomal DNA spacer-length polymorphisms in barley: Mendelian inheritance, chromosomal location, and population dynamics. Proc Natl Acad Sci U S A 81: 8014-8018.

Salazar B, Laurentin H, Davila M, Castillo MA. 2006. Reliability of the RAPD technique for germplasm analysis of Sesame (Sesamum indicum L.) from Venezuela. Interciencia 31: 456-460.

Sanchez de la Hoz MP, Davila JA, Loarce Y, Ferrer E. 1996. Simple sequence repeats primer used in PCR amplifications to study genetic diversity in barley. Genome 39: 112-117.

Sehr EM, Okello-Anyanga W, Hasel-Hohl K, et al. 2016. Assessment of genetic diversity amongst Ugandan sesame (Sesamum indicum L.) landraces based on agromorphological traits and genetic markers. J Crop Sci Biotechnol 19: 117-129.

Singh KM, Kumar DB, Kumar DS, Manorama. 2015. Assessment of genetic diversity among Indian Sesame (Sesamum indicum L.) accessions using RAPD, ISSR and SSR markers. Res J Biotechnol 10: $35-47$.

Skiredj A, El Attir H, El Fadl A. 2003. Fiche technique des cultures aromatiques et condimentaires. Department d'horticulture, IAV Hassan II, pp. 22. Available from https://studylibfr.com/doc/ 885224/3.cultures-aromatiques-legumieres (last consult: 2020/ 01/05).

Spawan KT, Kar J, Sahu D. 2019. Advances in sesame (Sesamum indicum L.) breeding. In: Al Khayri JM, Jain SM, Johnson DV, eds. Advances in plant breeding strategies: industrial and food crops. V6. Switzerland AG: Springer Nature, pp. 577-636.

Uncu AO, Gultekin V, Allmer J, Frary A, Doganlar S. 2015. Genomic simple sequence repeat markers reveal patterns of genetic relatedness and diversity in sesame. Plant Genome 8: 1-12.

Uzun B, Arslan C, Karhan M, Toker C. 2007. Fat and fatty acids of white lupin (Lupinus albus L.) in comparison to sesame (Sesamum indicum L.). Food Chem 102: 45-49.

Wang L, Yu S, Tong C, et al. 2014. Genome sequencing of the high oil crop sesame provides insight into oil biosynthesis. Genome Biol 15: R39.

Woldesenbet DT, Tesfaye K, Bekele E. 2015. Genetic diversity of sesame germplasm collection (Sesamum indicum L.): implication for conservation, improvement and use. Int J Biotechnol Mol Biol Res 6: 7-18.

Zhang YX, Zhang XR, Hua W, Wang LH, Che Z. 2010. Analysis of genetic diversity among indigenous landraces from sesame (Sesamum indicum L.) core collection in China as revealed by SRAP and SSR markers. Genes Genom 32(3): 207-215.

Cite this article as: El Harfi M, Charafi J, Houmanat K, Hanine H, Nabloussi A. 2021. Assessment of genetic diversity in Moroccan sesame (Sesamum indicum) using ISSR molecular markers. OCL 28: 3. 